\title{
CDC6 Gene
}

National Cancer Institute

\section{Source}

National Cancer Institute. CDC6 Gene. NCI Thesaurus. Code C20382.

This gene plays a role in regulation of the early steps of DNA replication. 